\title{
Women directors and exporting activity: The moderating role of network advice
}

\author{
Bochra Idris $^{1, *} \bullet$ George Saridakis ${ }^{2}$ \\ ${ }^{1}$ Aston Business School, Aston University, Birmingham, UK \\ ${ }^{2}$ Kent Business School, University of Kent, Canterbury, UK
}

Received: 18 September 2019

Revised: 24 January 2020

Accepted: 30 January 2020

\begin{abstract}
We use data from Small and Medium Sized Enterprises (SMEs) in the UK to examine the link between the presence of women directors and exporting activity. To do this, we build on resource-based view (RBV) and resource dependence theory (RDT) and show that SMEs with women on the board of directors are less likely to be involved in exporting activity compared to SMEs without women directors. Nevertheless, this negative relationship may be moderated by seeking network advice, which can be explained through the social network theory (SNT).
\end{abstract}

Keywords: women directors, small and medium-sized firms, exporting activity, network advice. JEL Classification Codes: F23, M16

\section{Introduction}

In recent years, increasing academic and policy attention has been paid to firms that are managed by women given their significant contribution to the economy and society (Farrell \& Hersch, 2005; Simpson et al., 2010; Hughes et al., 2012; Jennings \& Brush, 2013; Pergelova et al., 2018). Similarly, substantial effort has been made to strengthen women's engagement and involvement on boards and the decision-making process (Vinnicombe et al., 2008; Nielsen \& Huse, 2010; Martín-Ugedo \& Minguez-Vera, 2014). As a result of this, gender differences have become a focal topic for researchers in international business (IB), but also in entrepreneurship and small business research (Ratten \& Tajeddini, 2018). Much of the focus, however, has been on the practices used and challenges faced by women entrepreneurs as well as the need to understand their relevant enablers, drivers and performance factors (e.g., Tlaiss, 2015; Dean \& Ford, 2017; Stead, 2017). Therefore, the empirical literature has tended to pay much less attention to the relationship between women and exporting activity as a proxy of internationalization, which is important for firm competitiveness and growth (Andersson \& Wictor, 2003; Orser et al., 2010). Additionally, much of this small but increasing literature has

\footnotetext{
*E-mail: b.idris@aston.ac.uk.

Citation: Idris, B., and Saridakis, G. (2020) Women directors and exporting activity: The moderating role of network advice, Economics and Business Letters, 9(2), 106-113.
}

DOI: $10.17811 /$ ebl.9.2.2020.106-113 
produced mixed findings suggesting either a negative or an insignificant relationship between the two (see Westhead et al., 2001; Reavley et al., 2005; Pergelova et al., 2018) making the need for further research evidence more essential.

In this paper, we focus on SME directors, who are responsible for the internationalization strategy of the firm, (Rivas et al., 2009; Rivas et al., 2012; Arzubiaga et al., 2018) and following recent studies (e.g., Pergelova et al., 2018) we examine potential gender differences in exporting activity of the firms. To do so, we draw on the Resource Based View (RBV) and Resource Dependency Theory (RDT), which are well-established frameworks that are used to explain the internationalization of SMEs (Pfeffer \& Salancik, 1978; Duran \& Jordan, 2012; Laufs \& Schwens, 2014). We go beyond the existing literature by examining the moderating role of seeking network advice on the women directors-exporting activity, building on the recent work by Idris and Saridakis (2018). Using Social Network Theory (SNT), we argue that if a negative relationship between women directors and exporting activity exists, it will be weaker when seeking network advice since it may provide information and resources (Rosenbaum, 2017) to assist with the internationalization of the firm.

The paper is organized as follows. Section 2 discusses the literature and the research hypotheses. Section 3 briefly explains the data, the construction of the key variables and empirical specification. Section 4 explains the results and the analysis, and the last section concludes the paper.

\section{Literature review}

Entrepreneurship has been generally linked with 'masculine gender role stereotypes' (Gupta et al., 2009: 397) influencing negatively new or international business opportunities that are available to women (Gupta et al., 2014; Pergelova et al., 2018). In a growing body of literature, a number of barriers that affect women-led firms when attempting to expand their firms internationally have been identified. For example, compared to their male counterparts, women are more concerned about the risk of high-growth strategies and are keen to balance family and work responsibilities, so they may choose intentionally to operate in smaller-scale and local markets (Cliff, 1998; Kepler \& Shane, 2007). To this end, various studies in psychology and sociology converge towards the view that women are less likely to be risk-takers than men. Since internationalization via exporting is considered a risky strategy, they might decide not to expand their firms across borders (Aculai et al., 2006). Similarly, in the entrepreneurship literature, a woman entrepreneur is described as 'cautious, conservative and risk-averse' (Marlow \& McAdam, 2012: 664). According to Pergelova et al. (2018), such findings are of great importance since they show that independently of achieving high levels of firm performance, women entrepreneurs still exhibit lower perceptions of risk-taking compared to men.

Moreover, in line with the RBV and RDT, internal financial constraints and difficulties in accessing external financial resources can deter SMEs, especially women-led firms, from entering international markets (Laufs \& Schwens, 2014; Gicheva \& Link, 2015). Previous works find that although women are likely to exhibit similar financial self-confidence with men (e.g., Imarhiagbe et al., 2017), they are more likely to be financially constrained (e.g., Sabarwal \& Terrell, 2008) and report lower levels of external funding (Watson, 2006). This may be explained by gender differences and the likelihood of being rejected for a bank loan (e.g., Fraser, 2005) and levels of discouragement in applying for one (e.g., Bardasi et al., 2011). Hence, women-owned firms are generally smaller in size and concentrate on low-productivity sectors (e.g., World Bank Group, 2014). Turning to gender differences in internationalization through exporting, the results are ambiguous. Reavley et al. (2005), for example, report no evidence of gender challenges in international trade among seven 'award-winning' women exporters suggesting that there is no gender effect on exports. An earlier study by Grondin and 
Schaefar (1995) finds that women-owned Canadian SMEs that lack the readiness to export are less likely to undertake exporting activity, but gender is not reported as the primary reason for internationalization decisions. Additionally, Westhead et al. (2001), using data from the UK, find that gender has an insignificant impact on exports. However, such results could be due to unobserved moderating effects. Recently Lee et al. (2016) found that marketing competencies and innovation mediate the association between gender and exporting for Korean firms. Given the above literature, our first hypothesis is:

H1: SMEs with women directors on board are less likely to export than SMEs with no women directors on board.

The role of networks in the exporting activity of SMEs has received significant research attention over the past years (e.g., Boehe, 2013; Stoian et al., 2016; Idris \& Saridakis, 2018). To this end, the Social Network Theory suggests that owner-managers may be able to access needed external resources (e.g., financial and technological resources) that are necessary for their growth through their network channels (Florin et al., 2003; Idris \& Saridakis, 2018). Hence, entrepreneurs can use the networks that are available to them to gain access, for example, to knowledge and information that are beneficial for their internationalization decisions and strategies. However, women are less likely to seek 'male-dominant formal networks' (Rosenbaum, 2017: 120) (such as banks), thus restricting their access to mainly informal networks (e.g., family and friends) and not utilizing in full the potential benefits provided by participating in a wider range of networks (Brush, 1992; Hampton et al., 2009). Additionally, Ratten \& Tajeddini (2018) find that when women entrepreneurs use their networks, they tend to use them differently from the way male entrepreneurs use them.

For example, it has been noted that the status and self-esteem may impact women's networking behavior. According to Forret and Dougherty (2001) women with no family responsibilities tend to engage in similar networking behavior as males compared to women with family responsibilities who may experience difficulties should networking occur after working hours (Singh et al., 2006). Moreover, self-esteem has been found to positively and significantly affect networking behavior (Forret \& Dougherty, 2001). Similarly, some other studies suggest that women directors behave differently from their male counterparts. For example, women serving on the board of directors tend to question the process more, and they are more socially engaged and oriented than men (see Huse \& Solberg, 2006; Huse et al., 2009; Rosenbaum, 2017). Here, in line with Idris and Saridakis (2018) we argue that networks can play an important role in a firm's exporting activity as they assist firms in gaining foreign market knowledge and information needed for internationalization. Thus, if women seek network advice, the negative relationship between women directors and exporting can be suppressed. Hence, our second hypothesis is:

H2: Network advice moderates the relationship between women directors on board and SMEs exporting activity such that this negative relationship becomes weaker for firms with women directors on board.

\section{Data and key variables}

To test our two hypotheses, we use survey data with owner-managers of UK SMEs (firms with less than 249 employees) (SBS, 2015; BIS, 2016). The survey asks owner-managers if 'in the past 12 months, did your business export any goods and/or services outside the UK' (BIS, 2016: 34). Hence, a binary variable (i.e., 1: if the firm exports; 0: otherwise) is constructed and used as a proxy of internationalization (e.g., Serra et al., 2012; Idris \& Saridakis, 2018; Saridakis et al., 2019). 
Figure 1. Networking activities by exporting firms (that have at least one director who is not owner or partner, $n=7,123)$.

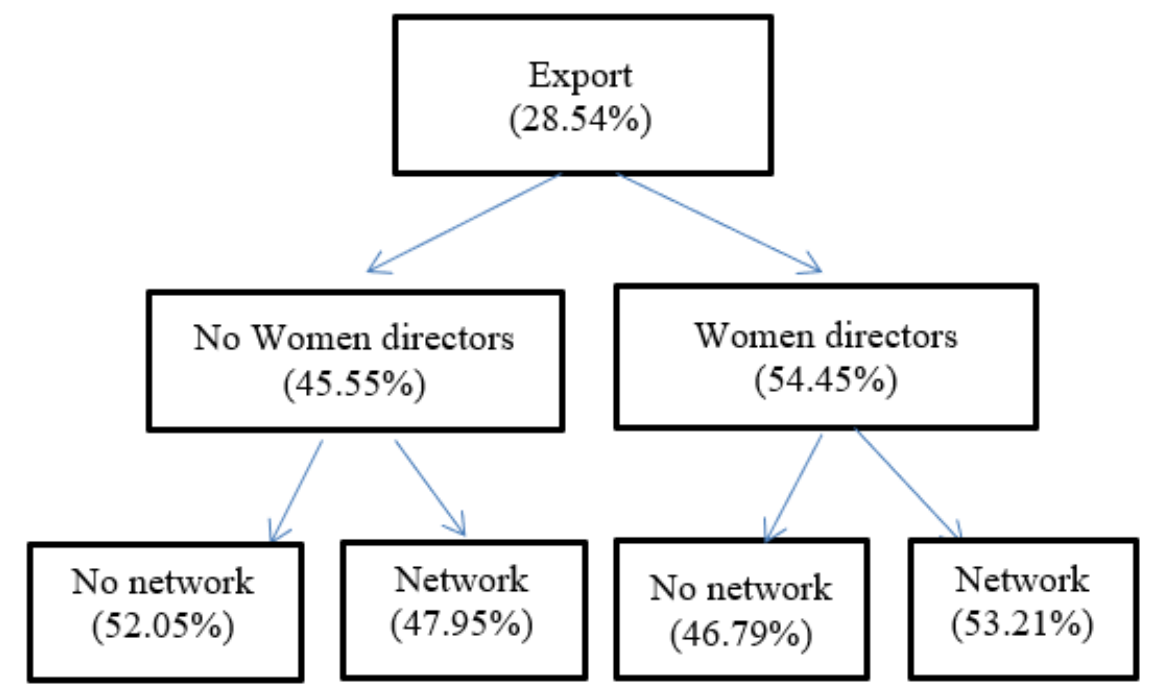

Figure 2. Networking activities by non-exporting firms (that have at least one director who is not owner or partner, $n=7,123$ )

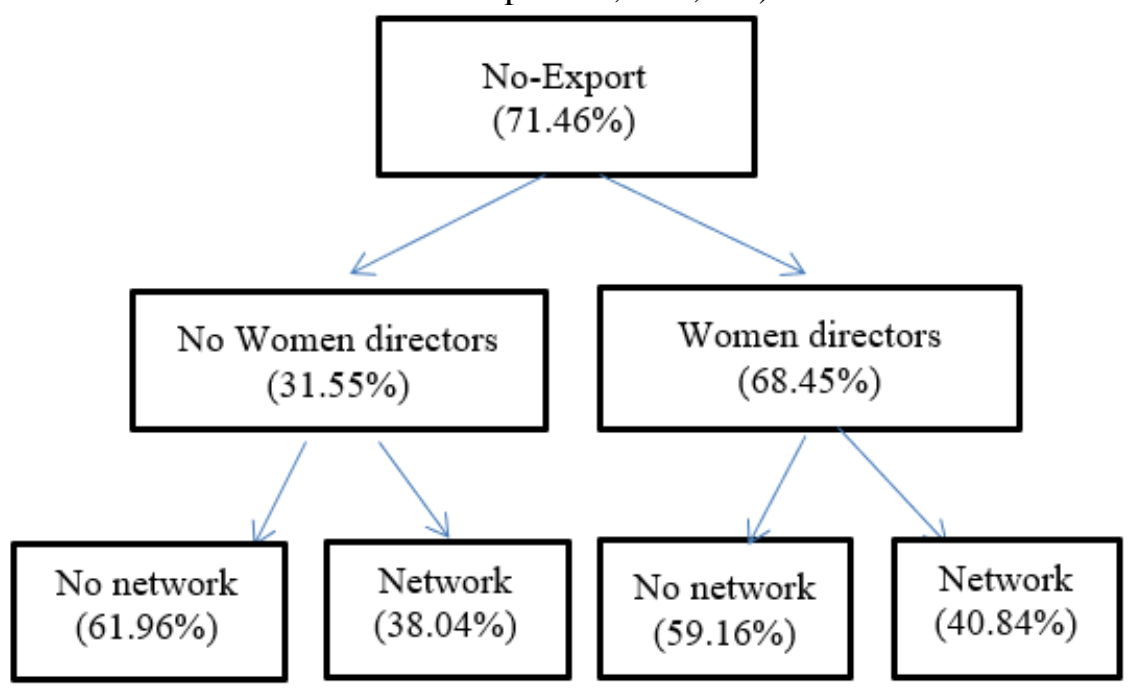

We consider network advice as a proxy of networking activity (see Sparrowe et al., 2001; Hoang \& Antoncic, 2003; Idris \& Saridakis, 2018). The survey asks owner-managers whether they sought external advice from formal/informal networks on matters affecting their businesses in the last 12 months (BIS, 2016: 73). Again, the network advice variable is a binary variable (1: if network advice was sought; 0 : if not).

Moreover, the survey asks firms that have any directors in the day-to-day control of the businesses who are not owners or partners and if any of those partners are women (BIS, 2016: 2829). The explanatory variable is, therefore, a binary variable (1: if the firm has women directors; 0 : otherwise).

Figures 1 and 2 represent the networking activities for exporting SMEs and non-exporting SMEs, respectively, with and without women directors on board. To estimate it, we use a probit model (see Wooldridge, 2010). 


\section{Empirical results}

In Table 1, we present the results from the probit model. Model 1 shows that firms that have women directors on board are less likely to export (by 3.6 percentage points estimated at mean values; see Model 1 column 2) than SMEs that do not have women directors on board. Hence, $H 1$ is supported. ${ }^{1}$ In Model 2, we include the interaction between seeking network advice and women directors on internationalization. The results from this model suggest a positive interaction between women directors on boards and seeking network advice with the marginal effect (ME) being equal to 0.038 (column 4); suggesting a suppressing effect of network advice on women directors-exporting activity relationship. However, following Ai and Norton (2003) and Norton et al (2004) the corrected magnitude of the mean effect is found to be in the region of 0.031 (Std. err. $=0.019){ }^{2}$ This is estimated as a difference in the marginal effect of women directors on exporting activity between those seeking network advice (ME=-0.017, Std. err. $=0.015)$ and those not $(\mathrm{ME}=-0.048$, Std. err. $=0.013)$.

Table 1. Probit estimates.

\begin{tabular}{lrrrr}
\hline \hline Probit & \multicolumn{2}{c}{ Model 1 } & \multicolumn{2}{c}{ Model 2 } \\
Model & Coef. & ME & Coef. & ME \\
\hline Women directors on board & $-0.121^{* * *}$ & $-0.036^{* * *}$ & $-0.192^{* * *}$ & $-0.057^{* * *}$ \\
& 0.039 & 0.011 & 0.052 & 0.015 \\
Seeking network advice & & & $0.190^{* * *}$ & $0.056^{* * *}$ \\
& & 0.058 & 0.017 \\
Women directors on board* & & $0.129^{*}$ & $0.038^{*}$ \\
Seeking network advice & & 0.074 & 0.022 \\
Controls & Yes & Yes & \\
log Likelihood & -3282.03 & -3254.16 & \\
$x^{2}(\mathrm{df})$ & $1954.96^{* * *}(42)$ & & $2010.70^{* * *}(44)$ & \\
\hline Obs. & 7,123 & \multicolumn{2}{c}{7,123} & \\
\hline \hline
\end{tabular}

Notes: Values in italics are the standard errors. Controls: Size of firm, firm age, legal status, number of sites, family firm, business environment, turnover, sectors and regions; $* * * p<0.01 ;{ }^{*}<<0.1$.

\section{Conclusion}

In this paper, we examine the association between women directors on boards in SMEs and exporting activity as a proxy of their internationalization strategies. Our results show that SMEs that have women directors on their boards are less likely to internationalize than firms that do not have women directors. This may be because women entrepreneurs face significant and different challenges compared to their male counterparts, such as difficulties in accessing financial capital, attitudes towards risks and work and family priorities (Aculai et al., 2006; Laufs \& Schwens, 2014; Gicheva \& Link, 2015).

However, our results show that only when women directors use network advice, the negative effect of women directors on boards is suppressed significantly. Therefore, it can be suggested that network advice can enable women directors to gain access to potentially useful information, knowledge and resources, which are needed for internationalization purposes. In other words,

\footnotetext{
${ }^{1}$ We also include in the specification the variable seeking network advice. The results from this model show that seeking network advice increases the likelihood of SMEs exporting (by 7.9 percentage points estimated at mean values) compared to SMEs that do not seek network advice. Moreover, propensity score matching techniques provide similar conclusions. Finally, a Wald test suggests that the coefficients for women directors found in this Model 1 is not significantly different from the coefficient reported here $\left(\mathrm{x}^{2}(1)=0.11\right.$, prob. $\left.=0.739\right)$.

${ }^{2}$ Although it is not reported here, we also find that the magnitude of the interaction effect, although it remains positive, varies between firms with low and high-predicted probabilities of undertaking an exporting activity.
} 
networks can act as a facilitator for internationalization in SMEs that have women on their boards as directors. Our results, therefore, provide some new findings that can be used by SMEs, policymakers and practitioners to stimulate exporting activity in SMEs with women directors on board.

\section{References}

Aculai, E., Rodionova, N., and Vinogradova, N. (2006) Women business owners in Moldova: Proprietors or entrepreneurs? In Welter, F., Smallbone, D., and Isakova, N. (Eds): Enterprising Women in Transition Economies. Aldershot: Ashgate Publishing, 67-91.

Andersson, S., and Wictor, I. (2003) Innovative internationalization in new firms: Born globals - the Swedish case, Journal of International Entrepreneurship, 1(3), 249-276.

Arzubiaga, U., Iturralde, T., Maseda, A., and Kotlar, J. (2018) Entrepreneurial orientation and firm performance in family SMEs: The moderating effects of family, women, and strategic involvement in the board of directors, International Entrepreneurship Management Journal, $14(1), 217-244$.

Ai, C., and Norton, E. C. (2003) Interaction terms in logit and probit models, Economics Letters, 80(1), 123-129.

Bardasi, E., Sabarwal, S., and Terrell, K. (2011) How do female entrepreneurs perform? Evidence from three developing regions, Small Business Economics, 37(4), 417-441.

Boehe, D. (2013) Collaborate at home to win abroad: How does access to local network resources influence export behaviour? Journal of Small Business Management, 51(2), 167182.

Brush, C. G. (1992) Research on women business owners: Past trends, a new perspective, and future directions, Entrepreneurship Theory \& Practice, 16(4), 5-30.

Cliff, J. (1998) Does one size fit all? Exploring the relationship between attitudes towards growth, gender and business size, Journal of Business Venturing, 13(6), 523-542.

Dean, H., and Ford, J. (2017). Discourses of entrepreneurial leadership: Exposing myths and exploring new approaches, International Small Business Journal, 35(2), 178-196.

Department for Business, Innovation and Skills (BIS) (2016) Longitudinal small business survey, year one, 2015, [data collection], UK data service. http://dx.doi.org/10.5255/ UKDA-SN-7973-1 (Accessed 20 August 2016).

Durand, R., and Jourdan, J. (2012). Jules or Jim: Alternative conformity to minority logics, Academy of Management Journal, 55(6), 1295-1315.

Farrell, K. A., and Hersch, P. L. (2005). Additions to corporate boards: The Effect of gender, Journal of Corporate Finance, 11(1/2), 85-206.

Florin, J., Lubatkin, M., and Schulze, W. (2003). A social capital model of high-growth ventures, Academy of Management Journal, 46(3), 374-384.

Forret, N. L., and Dougherty, T.W. (2001) Correlates of networking behavior for managerial and professional employees, Group \& Organization Management, 26(3), 283-311.

Fraser, N. (2005) Mapping the feminist imagination: From redistribution to recognition to representation, Constellations: An International Journal of Critical and Democratic Theory, 12(3), 295-307.

Gicheva, D., and Link, A.N. (2015) The gender gap in federal and private support for entrepreneurship, Small Business Economics, 45(4), 729-733.

Grondin, D., and Schaefer, N. (1995) Differences in the export activities of female and maleowned SME enterprises, Women in Management Review, 10(8), 4-10.

Gupta, V. K., Goktan, A. B., and Gunay, G. (2014) Gender differences in evaluation of new business opportunity: A stereotype threat perspective, Journal of Business Venturing, 29(2), 273-288.

Gupta, V. K., Turban, D., Wasti, S. A., and Sikdar, A. (2009) The role of gender stereotypes in 
perceptions of entrepreneurs and intentions to become an entrepreneur, Entrepreneurship Theory and Practice, 33(2), 397-417.

Hampton, A., Cooper, S., and McGowan, P. (2009). Female entrepreneurial networks and networking activity in technology-based ventures: An exploratory study, International Small Business Journal, 27(2), 193-214.

Hoang, H., and Antoncic, B. (2003) Network-based research in entrepreneurship: A critical review, Journal of Business Venturing, 18(2), 165-187.

Hughes, K., Jennings, J., Brush, C., Carter, C., and Welter, F. (2012) Extending women's entrepreneurship research in new directions, Entrepreneurship Theory and Practice, 36(3), 429-442.

Huse, M., Nielsen, S., and Hagen, I. M (2009) Women and employee-elected board members, and their contributions to board control tasks, Journal of Business Ethics, 89, 581- 597.

Huse, M., and Solberg, A .G. (2006) Gender related boardroom dynamics: How women make and can make contributions on corporate boards, Women in Management Review, 21, 113130.

Idris, B., and Saridakis, G. (2018) Local interpersonal networks and SMEs internationalization: Empirical evidence from the UK, International Business Review, 27(3), 610-624.

Imarhiagbe, B. O., Saridakis, G., and Mohammed, A. M. (2017) Do bank credit rejection and financial education affect financial self-confidence? International Journal of Entrepreneurial Behavior \& Research, 23(6), 1033-1051.

Jennings, J. E., and Brush, C. (2013) Research on women entrepreneurs: Challenges to (and from) the broader entrepreneurship literature? Academy of Management Annals, 7(1), 663715.

Kepler, E., and Shane, S. (2007) Are male and female entrepreneurs really that different? The Office of Advocacy Small Business Working papers 07ekss, U.S. Small Business Administration, Office of Advocacy.

Laufs, K., and Schwens, C. (2014) Foreign market entry mode choice of small and mediumsized enterprises: A systematic review and future research agenda, International Business Review, 23, 1109-1126.

Lee, H., Paik, Y., and Uygur, U. (2016) Does gender matter in the export performance of international new ventures? Mediation effects of firm-specific and country-specific advantages, Journal of International Management, 22, 365-379.

Marlow, S., and McAdam, M. (2012) Analyzing the influence of gender upon high-technology venturing within the context of business incubation, Entrepreneurship Theory and Practice, 36(4), 655-676.

Martín-Ugedo, J. F., and Minguez-Vera, A. (2014) Firm performance and women on the board: Evidence from Spanish small and medium-sized enterprises, Feminist Economics, 20(3), 136-162.

Nielsen, S., and Huse, M. (2010) Women directors and board strategic decision-making: The moderating role of equality perception, European Management Review, 7(1), 16-29.

Norton, E. C., Wang, H., and Ai, C. (2004) Computing interaction effects and standard errors in logit and probit models, The Stata Journal, 4(2), 154-167.

Orser, B., Spence, M., Riding, A., and Carrington, C. (2010) Gender and export propensity, Entrepreneurship Theory and Practice, 34(5), 933-957.

Pfeffer, J., and Salancik, G. R. (1978) The external control of organizations: A resource dependence Approach, NY: Harper and Row Publishers.

Pergelova, A., Angulo-Ruiz, F., and Yordanova, D. I. (2018) Gender and international entry mode, International Small Business Journal: Researching Entrepreneurship, 36(6), 662685.

Ratten, V., and Tajeddini, K. (2018) Women's entrepreneurship and internationalization: 
Patterns and trends, International Journal of Sociology and Social Policy, 38(9/10), 780793.

Reavley, M., Lituchy, T., and McClelland, E. (2005) Exporting success: A two-country comparison of women entrepreneurs in international trade, International Journal of Entrepreneurial and Small Business, 2(1), 57-78.

Rivas, J. L., Hamori, M., and Mayo, M. (2009) Board composition and firm internationalization, Academy of management proceedings, 1, 1-6.

Rivas, J. L. (2012) Diversity \& internationalization: The case of boards and TMT's, International Business Review, 21(1), 1-12.

Rosenbaum, G. O. (2017) Female entrepreneurial networks and foreign market entry, Journal of Small Business and Enterprise Development, 24(1), 119-135.

Sabarwal, S., and Terrell, K. (2008) Does gender matter for firm performance? Evidence from Eastern Europe and Central Asia. World Bank Policy Research Working Paper Series No.4705. Available at: https://ssrn.com/abstract $=1262646$. Last access on the $16^{\text {th }}$ of July 2019.

Saridakis, G., Idris, B., Hansen, J. M., and Dana, L-P. (2019) SMEs internationalization: When does innovation matters? Journal of Business Research, 96, 250-263.

Serra, F., Pointon, J., and Abdou, H. (2012) Factors influencing the propensity to export: A study of UK and Portuguese textile firms, International Business Review, 21, 210-224.

Simpson, W. G., Carter, D., and D'Souza, F. P. (2010). What do we know about women on boards? Journal of Applied Finance, 20(2), 27-39.

Singh, V., Vinnicombe, S., andKumra, S. (2006) Women in formal corporate networks: an organisational citizenship perspective, Women in Management Review, 21(6), 458-482.

Sparrowe, R., Liden, R. C., Wayne, S. J., and Kraimer, M. L. (2001) Social networks and the performance of individuals and groups, Academy of Management Journal, 44(2), 316-325

Stoian, M. C., Rialp, A., Rialp, J., and Jarvis, R. (2016). Internationalisation of Central and Eastern European small firms: Institutions, resources and networks, Journal of Small Business and Enterprise Development, 23(1), 105-121.

Stead, V. (2017) Belonging and women entrepreneurs: Women's navigation of gendered assumptions in entrepreneurial practice, International Small Business Journal, 35(1), 61-77.

Tlaiss, H. (2015) Entrepreneurial motivations of women: Evidence from the United Arab Emirates, International Small Business Journal, 33(5), 562-581.

Vinnicombe, S., Singh, V., Burke, R.J., Bilimoria, D., and Huse, M. (2008) Women on corporate boards of directors: International research and practice. London: E. Elgar.

Watson, J. (2006) External funding and firm growth: Comparing female- and male-controlled SMEs, Venture Capital, 8(1), 33-49.

Westhead, P., Wright, M., and Ucbasaran, D. (2001). The internationalization of new and small firms: A resource-based view, Journal of Business Venturing, 16, 333-358.

Wooldridge, J. M. (2010) Econometric analysis of cross section and panel data, $2^{\text {nd }}$ ed, U.S.A: Massachusetts Institute of Technology.

World Bank. (2014) The World Bank annual report 2014 : Main report (English). Washington, DC: World Bank Group. http://documents.worldbank.org/curated/en/11178 14681709529 58/Main-report 